\title{
Karakterisasi Buah Dua Puluh Enam Genotipe Melon pada Media Pasir Sistem Hidroponik
}

\author{
Umi Salamah ${ }^{1}{ }^{*}$, Helfi Eka Saputra ${ }^{1}$ dan Welly Herman ${ }^{2}$ \\ ${ }^{1}$ Program Studi Agroekoteknologi, Fakultas Pertanian, Universitas Bengkulu \\ ${ }^{2}$ Program Studi Ilmu Tanah, Fakultas Pertanian, Universitas Bengkulu \\ *E-mail: umisalamah@unib.ac.id
}

DOI: https://doi.org/10.33369/pendipa.5.2.195-203

\begin{abstract}
ABSTRAK
Karakterisasi merupakan langkah awal dalam pemuliaan untuk melakukan seleksi terhadap karakter-karakter yang menjadi target. Melon (Cucumis melo L.) merupakan tanaman hortikultura yang memiliki karakter bervariasi. Penelitian ini bertujuan untuk mengkarakterisasi 26 genotipegenotipe melon di media pasir menggunakan sistem hidroponik. Penelitian ini menggunakan Rancangan Kelompok Lengkap Teracak (RKLT) dengan satu faktor yaitu genotipe yang terdiri dari 2 ulangan. Jumlah genotipe yang diuji adalah 26 yaitu G23, G27, G28, G29, G38, G39, G40, G41, G42, G43, G45, G46, G47, G48, G49, G52, G53, G55, G57, G58, G60, G62, G63, G64, G65 dan G66. Berdasarkan analisis gerombol didapatkan bahwa karakter-karakter pada 26 genotipe melon mengelompok dan terpisah pada koefesien ketidakmiripan 22 dan 26. Karakterisasi buah yang diamati adalah panjang buah, diameter buah, bentuk penampang membujur, warna dasar kulit buah matang, intensitas warna kulit saat matang, corak dasar warna kulit, warna kulit sekunder, kerapatan noktah, ukuran noktah, warna noktah, intensitas warna noktah, warna utama daging buah, warna lapisan luar daging buah, alur buah, posisi diameter maksimum, bentuk pangkal buah, dan bentuk ujung buah.
\end{abstract}

Kata kunci: Pemuliaan tanaman; analisis gerombol; karakterisasi.

\begin{abstract}
Characterization is the first step in breeding to select the target characters. Melon (Cucumis melo L.) is a horticultural plant that has varied characters. This study aims to characterize 26 melon genotypes in sand media using a hydroponic system. This study used a completely randomized block design (RKLT) with one factor, namely a genotype consisting of 2 replications. The number of genotypes tested was 26, namely G23, G27, G28, G29, G38, G39, G40, G41, G42, G43, G45, G46, G47, G48, G49, G52, G53, G55, G57, G58, G60, G62, G63, G64, G65, and G66. Based on cluster analysis, it was found that the characters in 26 genotypes of melon were grouped and separated at a coefficient of discrepancy 22 and 26. The fruit characterizations observed were fruit length, fruit diameter, longitudinal cross-section shape, basic color of ripe fruit skin, the intensity of skin color when ripe, and patterns. basic skin color, secondary skin color, dot density, dot size, dot color, dots color intensity, the main color of fruit flesh, the outer layer of fruit flesh, fruit groove, maximum diameter position, fruit base shape, and fruit tip shape.
\end{abstract}

Keywords: Plant breeding; cluster analysis; characterization.

\section{PENDAHULUAN}

Melon merupakan tanaman hortikultura memiliki nilai ekonomi yang penting dan banyak diminati masyarakat (Garcia-Mas et al., 2012). Hal ini terlihat dari sebaran tren data sekitar 3 tahun terakhir yaitu 2017 sebesar 92.434 ton, tahun 2018 sebesar 118.708 ton, dan tahun 2019 sebesar 122.105 ton. Persentase peningkatan sebanyak 77,86\%dari tahun 2017 ke tahun 2018 dan 97,22\% dari tahun 2018 sampai tahun 2019 (Badan Pusat Statistik, 2019). Kenaikan tersebut membutuhkan pengembangan dalam budidaya tanaman melon.

Bengkulu merupakan lahan berpasir yang dapat dimanfaatkan untuk pengembangan budidaya melon melalui sistem hidroponik. Kota Bengkulu merupakan salah satu wilayah administrasi yang mempunyai wilayah kecamatan pesisir yang cukup luas (Fauzi et al., 
2009). Sumber daya wilayah pesisir di daerah ini pada umumnya belum dikelola dan dimanfaatkan secara optimal. Pasir dapat dimanfaatkan sebagai media tanam melalui sistem hidroponik. Hidroponik merupakan metode bercocok tanam dengan menggunakan media tanam selain tanah (Roidah, 2015). Sistem hidroponik dapat melakukan penyiraman dan pemupukan secara bersamaan sehingga memudahkan pekerjaan dan tepat sasaran (Heribawa dan Budiana, 2014). Penggunaan media pasir telah dilakukan percobaan pada beberapa tanaman hortikultura seperti bawang merah, tomat, terong, dan pakcoy (Sobilhaqq, 2015; Satya danFerdyana, 2017; Putra et al., 2013; Wahyuningsih et al., 2013). Namun, belum banyak dicujicobakan pada melon.

Family Cucurbitaceae memiliki 825 spesies yang tergolong bervariasi, termasuk di dalamnya pumpkin, semangka, labu, luffa, beberapa jenis gulma dan melon (Kerje, 2003). Melon dikelompokkan menjadi beberapa grup kultivar yaitu Cucumis melo var. reticulatus, Cucumis melo var. inodorus, dan Cucumis melo var. cantalupensis (Robinson and DeckerWalters, 1999). Melon (Cucumis melo L.) merupakan tanaman hortikultura yang memiliki karakter bervariasi (Kerje, 2003). Keragaman karakter buah dapat berupa bentuk buah, ukuran buah, warna kulit, warna daging buah, tekstur kulit, padatan terlarut total, aroma, dan ketahanan hama penyakit, perbedaan jenis buah berdasarkan produksi etilen dan lain-lain (Rakhi dan Rajamony, 2006). Karakterisasi merupakan langkah awal dalam pemuliaan untuk melakukan seleksi terhadap karakterkarakter yang menjadi target atas dasar ciriciri fenotip/morfologi (Nuraida, 2012; Glen et al., 2017; Weber et al., 2012). Melalui kegiatan pemuliaan tanaman, diharapkan dapat dihasilkan varietas-varietas melon baru yang lebih bervariasi dan menarik minat konsumen (Huda et al., 2017).

Penelitian ini bertujuan untuk mengkarakterisasi 26 genotipe-genotipe melon di media pasir menggunakan sistem hidroponik.

\section{METODOLOGI PENELITIAN}

\section{Lokasi dan Waktu Penelitian}

Penelitian telah dilaksanakan di Rumah Kaca Laboratorium Agronomi Fakultas
Pertanian Universitas Bengkulu. Penelitian dilaksanakan dari Juli hingga November 2020.

\section{Rancangan Penelitian}

Penelitian ini menggunakan

Rancangan Kelompok Lengkap Teracak (RKLT) dengan satu faktor yaitu genotipe yang terdiri dari 2 ulangan. Jumlah genotipe yang diuji adalah 26 yaitu G23, G27, G28, G29, G38, G39, G40, G41, G42, G43, G45, G46, G47, G48, G49, G52, G53, G55, G57, G58, G60, G62, G63, G64, G65 dan G66. Total satuan percobaan adalah 52 satuan percobaan.

Penanaman melon dilakukan menggunakan media pasir secara hidroponik. Pasir yang digunakan dimasukkan ke dalam polybag sebagai wadah. Polybag yang telah berisi media pasir diletakkan di atas ember plastik yang berisi larutan hara. Larutan hara yang digunakan adalah AB mix. Agar larutan hara naik ke media pasir maka setiap polybag diberi kain flannel.

Pembuatan larutan hara berasal dari stok A dan stok B yang dibuat secara terpisah. Konsentrasi hara yang diberikan adalah 5 $\mathrm{ml} / \mathrm{L}$ stok $\mathrm{A}+5 \mathrm{ml} / \mathrm{L}$ stok B selama fase vegetatif tanaman, apabila sudah terbentuk buah maka konsentrasi dinaikkan menjadi 7,5 $\mathrm{ml} / \mathrm{L}$ stok A + 7,5 ml/L stok B. Pemberian hara dilakukan setiap dua hari sekali ke dalam ember plastik sampai penuh. Pengendalian organisme pengganggu tanaman dilakukan secara berkala dengan menyemprotkan insektisida berbahan aktif Diapentiuron 500 $\mathrm{g} / \mathrm{L}$ konsentrasi $1 \mathrm{ml} / \mathrm{L}$ dan fungisida berbahan aktif Azoksistrobin $200 \mathrm{~g} / \mathrm{L}$ dan Difenokonazol $125 \mathrm{~g} / \mathrm{L}$ konsentrasi $1 \mathrm{ml} / \mathrm{L}$ setiap minggu sejak tanaman berumur dua minggu setelah tanam. Kegiatan pemanenan akan dilakukan pada saat melon telah mencapai tingkat kematangan $75 \%$. Pemanenan dilakukan pada setiap tanaman tetua resipien sebanyak $5-10$ buah per tanaman setiap kali panen. Pemanenan akan dilakukan setiap minggu selama 8 minggu.

Variabel yang diamati adalah panjang buah, diameter buah, bentuk penampang membujur, warna dasar kulit buah matang, intensitas warna kulit saat matang, corak dasar warna kulit, warna kulit sekunder, kerapatan noktah, ukuran noktah, warna noktah, intensitas warna noktah, warna utama daging buah, warna 
lapisan luar daging buah, alur buah, posisi diameter maksimum, bentuk pangkal buah, dan bentuk ujung buah.

Pengelompokan genotipe dilakukan dengan menggunakan analisis gerombol dan pengamatan karakterisasi disajikan dengan diagram batang.

\section{HASIL DAN PEMBAHASAN}

\section{Pengelompokkan genotipe melon berdasarkan karakter buah}

Bagian buah adalah bagian yang dikonsumsi pada tanaman melon. Bagian yang dimakan dari buah melon adalah daging buah dikenal dengan mesokarp. Tekstur daging buahb biasanya lunak, berwarna putih sampai merah. Rasa manis pada buah melon merupakan kombinasi dari berbagai faktor yang terkait dengan pengisian karbohidrat pada buah secara optimum serta konversi karbohidrat menjadi gula yang sempurna sehingga konsentrasi gula dalam cairan sel meningkat. Beragam karakter dapat diamati dari buah melon baik bentuk, rasa, dan warna dari berbagai sisi. Penggunaan media hidroponik pada tanaman melon sedikit banyak mempengaruhi perkembangan buah melon.

Koleksi adalah langkah awal dalam pemuliaan untuk mendapatkan informasi karakterisasi. Karakterisasi plasma nutfah dapat dimanfaatkan untuk perbaikan populasi (Liu et al., 2003; Ortiz et al., 2010). Melalui karakterisasi akan diperoleh beberapa informasi dari sifat suatu tanaman. Karakterisasi akan menghasilkan pengelompokan-pengelompokan berdasarkan beberapa sifat. Salah satu analisis yang sering digunakan untuk pengelompokan ini adalah analisis gerombol (cluster). Analisis gerombol merupakan analisis multivariat yang bertujuan untuk mengelompokkan objekobjek dari data yang diteliti berdasarkan kesamaan karakteristik yang dimilikinya (Ariawan et al., 2013). Analisis gerombol pada 26 genotipe buah melon menjadi dua kelompok pada koefesien ketidakmiripan sebesar 26 (Gambar 1). Kelompok pertama terdiri dari 3 genotipe yaitu 28,57 dan 42 . Sedangkan untuk kelompok kedua terdiri dari 23 genotipe melon. Pada koefesien ketidakmiripian 22 terbagi menjadi tiga kelompok genotipe. Kelompok pertama terdiri dari 3 genotipe seperti pada jarak 26 . Kelompok kedua terdiri dari 4 genotipe yaitu 23, 53, 47, dan 41. Sedangkan kelompok ketiga terdiri dari dari 19 genotipe. Salamah et al., (2016) menunujukkan bahwa genotipegenotipe generasi $S_{2}$ pada tanaman jagung secara keseluruhan terbagi menjadi dua bagian yaitu mengelompok dan terpisah sendiri dengan koefisien ketidakmiripan sekitar 0.34. Genotipe dengan kelompok yang sama berarti memiliki sifat yang hampir mirip. Perbedaan kelompok menunjukkan nilai ketidakmiripan antar genotipe. Nilai koefisien ketidakmiripan yang semakin besar menunjukan adanya perbedaan genetik yang semakin jauh antar genotipe. Populasi yang unggul dibangun dari sumber plasma nutfah yang memiliki keragaman genetik besar. Dalam pemilihan tetua baru perlu adanya jarak genetik antar tetua guna memberikan peluang dalam menghasilkan kultivar baru dengan variabilitas genetik luas (Tenda et al. 2009).

\section{Dekripisi karakterisasi buah pada 26 genotipe melon}

Karakteristik menandakan ciri dari suatu sifat dalam hal ini adalah buah melon. Pada satu buah dapat diidentifikasi bermacammacam sifat dengan beragam kriteria. Bentuk penampang membujur 26 genotipe buah melon terdapat 8 kriteria. Terdapat 2 genotipe buah melon pada masing-masing bentuk bulat telur, bulat telur terbaik, elip dan melebar. Sedangkan bentuk oblat dan bundar adalah bentuk paling banyak. Menurut Sari dan Solmaz (2007) bentuk bulat telur adalah bentuk paling banyak pada 67 genotipe melon lokal Turki. Bentuk pangkal buah 20 bentuk bulat, dan kurang dari 10 genotipe berbentuk datar dan runcing, begitujuga pada bentuk ujung buah ada dua kriteria. Bentuk bulat berjumlah lebih dari 20 sedangkan bentuk datar kurang dari 5 genotipe (Gambar 2).

Kriteria warna dasar kulit buah matang pada 26 melon yaitu warna hijau terdapat 4 genotipe lebih banyak dari warna putih. Terdapat 5 genotipe yang berwarna oker, 6 genotipe warna kuning hijau, dan warna kuning adalah warna terbanyak dengan jumlah genotipe adalah 8 . Intensitas warna kulit saat matang dibagi menjadi 3 kriteria. Pada kriteria gelap terdapat 3 genotipe, warna sedang 10 genotipe dan warna terang terdapat 13 genotipe. Kriteria corak dasar warna kulit. Warna 
kehijauan dan oren masing-masing terdiri dari 2 genotipe, kekuningan 3 genotipe, keputihputihan 8 genotipe dan paling banyak adalah yang tidak memiliki corak dasar warna kulit sebanyak 10 genotipe (Gambar 3). Daryono et al.,(2012) menyatakan bahwa Melon MG-3 hasil persilangan MG 1 (betina) dengan Ladika (jantan) memilik karakter warna kulit buah kuning dan warna daging buah orange, tekstur daging lembut, rasa manis, aroma harum, serta warna biji krem.

Pada 26 genotipe melon yang diuji ada yang memunculkan warna sekunder dan ada yang tidak memunculkan warna sekunder. Sebaran yang memunculkan warna sekunder berupa noktah lebih banyak daripada noktah dengan tambalan. Kerapatan noktah 26 genotipe buah melon kriteria sangat rapat adalah yang paling banyak sebanyak 8 genotipe diikuti dengan kriteria raoat sebanyak 6 genotipe, sedang 3 genotipe dan jarang 1 genotipe. Ada beberapa genotipe yang tidak ada dan jarang kerapatan noktahnya. Untuk ukuran noktah, ukuran kecil adalah ukuran paling banyak diikuti ukuran sedang dan besar. Sedangkan untuk warna noktah warna putih adalah warna paling banyak lebih dari 12 genotipe diikuti oleh warna kuning dan hijau (Gambar 4).

Menurut Afandi (2008) melon Sunpride memiliki 3 jenis melon, yaitu Rock Melon (Daging buah berwarna orange, berbentuk bulat hamper seragam dengan kulit bertekstur), Honey Melon (daging berwarna hijau muda tebal, kulit berwarna putih mengkilat dengan permukaan halus) dan Golden Melon (daging berwarna putih, dengan kulit berwarna kuning cerah). Daging buah merupakan bagian yang dikinsumsi pada buah melon. Dari 26 genotipe uji warna daging buah yang puith dan putih kekuningan memiliki genotipe terbanyak diikuti warna putih kehijauan. Warna orangen dan orange kemerahan masing-masing terdapat 3 genotipe dan warna hijau adalah warna yang paling sedikit yaitu 1 genotipe. Pada warna daging buah warna terang adalah warna paling banyak yaitu 14 genotipe, warna sedang 9 genotipe, dan warna gelap adalah 4 genotipe. Warna lapisan luar daging buah adalah warna hijau yang paling banyak yaitu diatas 20 genotipe sedangkan warna orange dan warna cream tidak kurang dari 5 genotipe. Menurut Ezura dan Owino (2008), melon yang memiliki warna daging buah oranye umumnya menghasilkan produksi etilen yang lebih tinggi dibandingkan dengan melon yang memiliki warna daging buah hijau atau putih. Umumnya melon dengan warna daging buah hijau atau putih memiliki daya simpan yang lebih baik (Gambar 5).

Pada 26 genotipe melon alur buah dengan kriteria kuat adalah 2 genotipe yang menunjukkan jumah paling sedikit, untuk lemah dan sangat lemah ada 7 genotipe dan sebagian tidak ada alur. Sedang untuk posisi diameter maksimum posisi tengah adalah posisi paling banyak dibanding posisi menuju ujung buah (Gambar 6). 


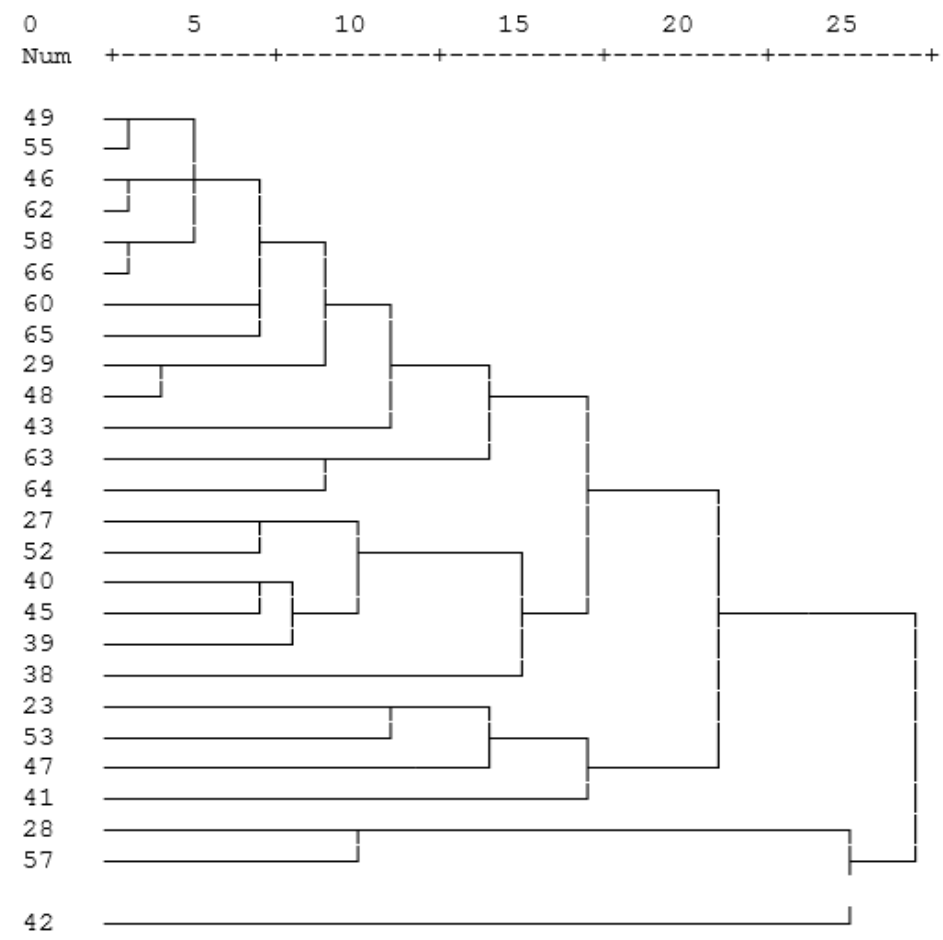

Gambar 1. Dendogram pada karakteristik 26 genotipe melon

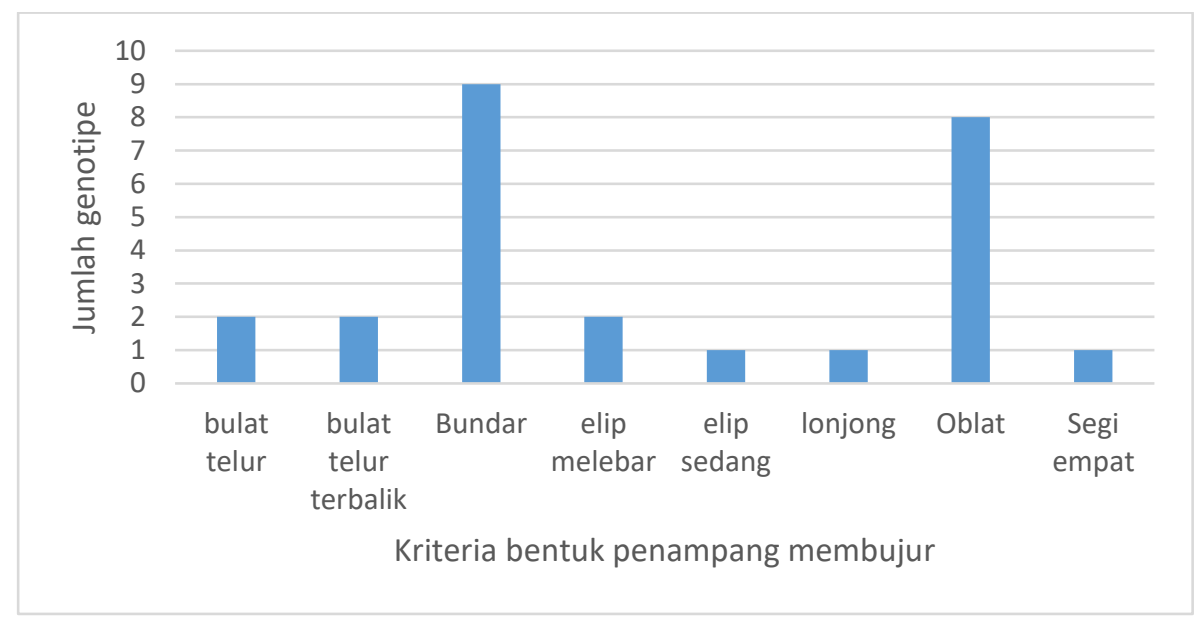

a

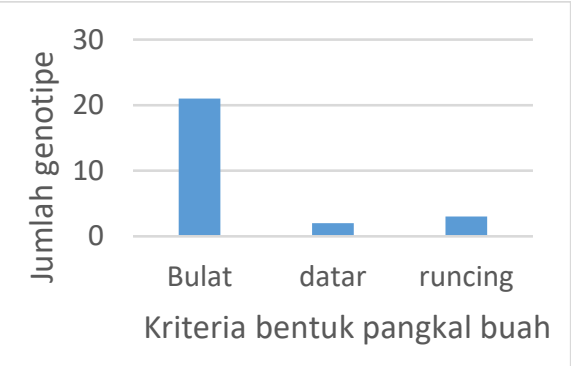

b

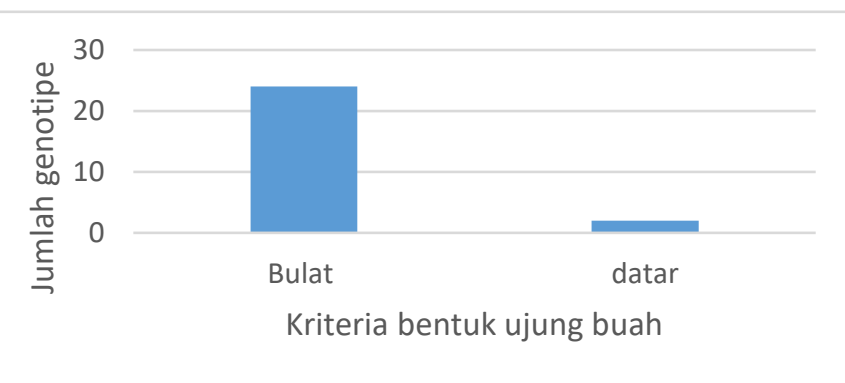

$\mathrm{c}$

Gambar 2. Grafik jumlah genotipe melon pada bentuk penampang membujur (a), bentuk pangkal buah (b) dan bentuk ujung buah (c) 


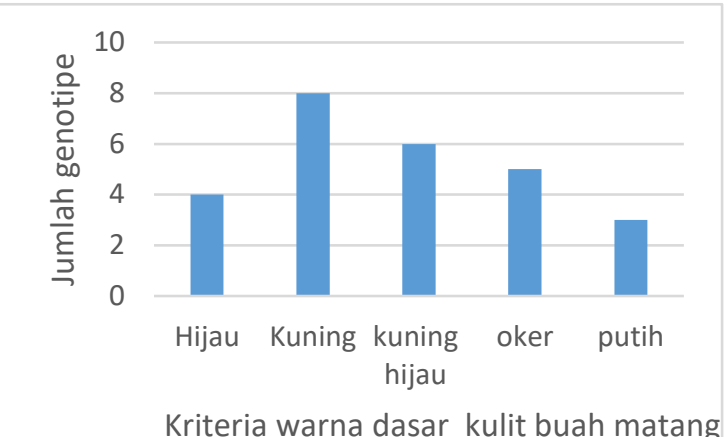

Kriteria warna dasar kulit buah matang

a

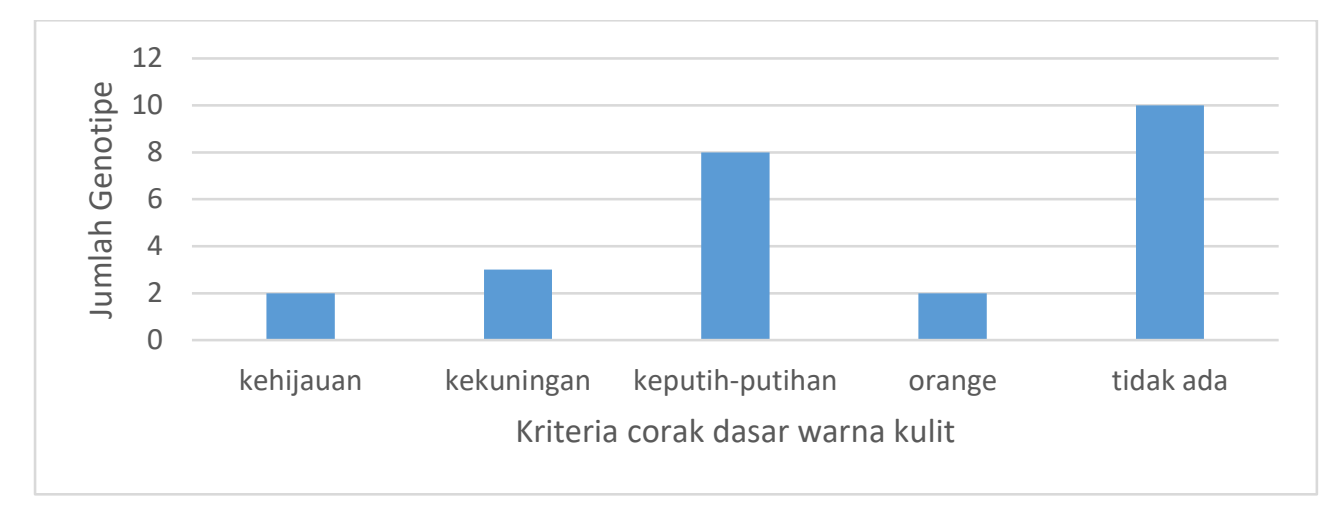

$\mathrm{c}$

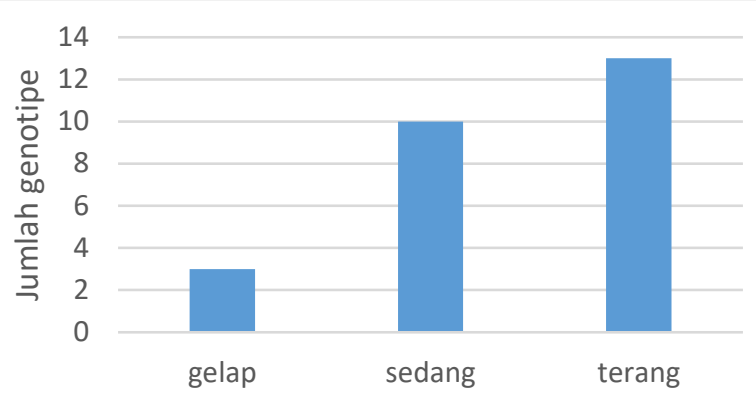

Kriteria intensitas warna kulit saat matang

b

Gambar 3. Grafik jumlah genotipe melon pada warna dasar kulit buah matang (a), intensitas warna kulit saat matang (b), dan corak dasar warna kulit (c)

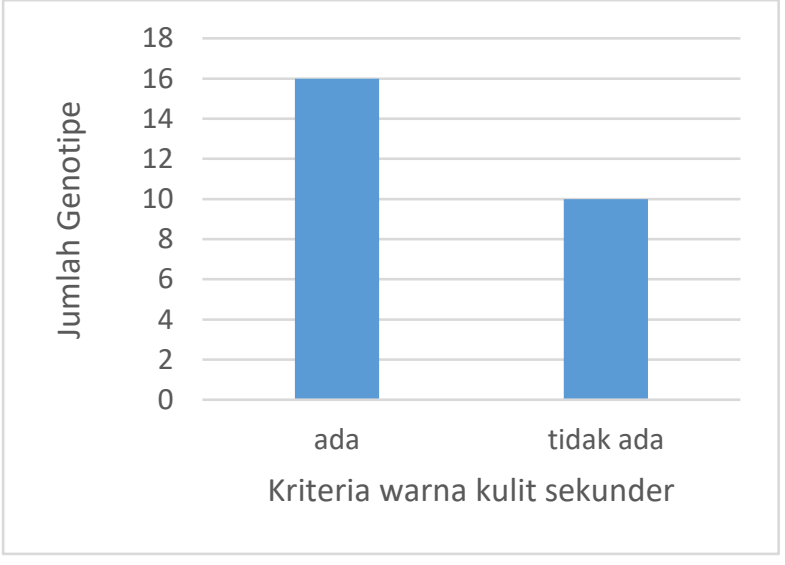

a

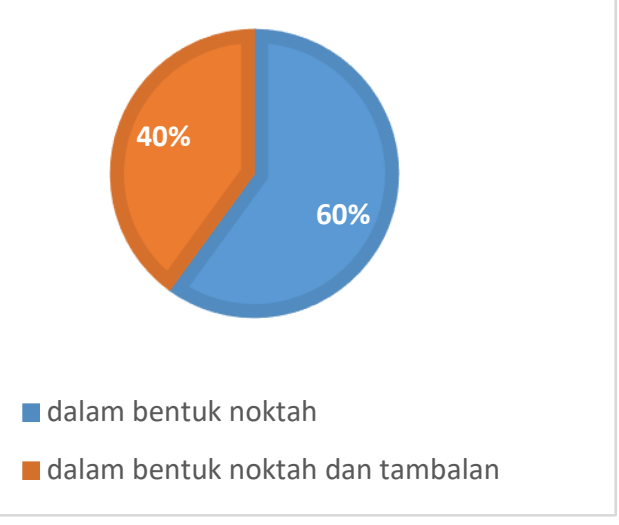

b

Gambar 4. Grafik jumlah genotipe melon pada warna kulit sekunder (a) dan sebaran warna kulit sekunder (b) 

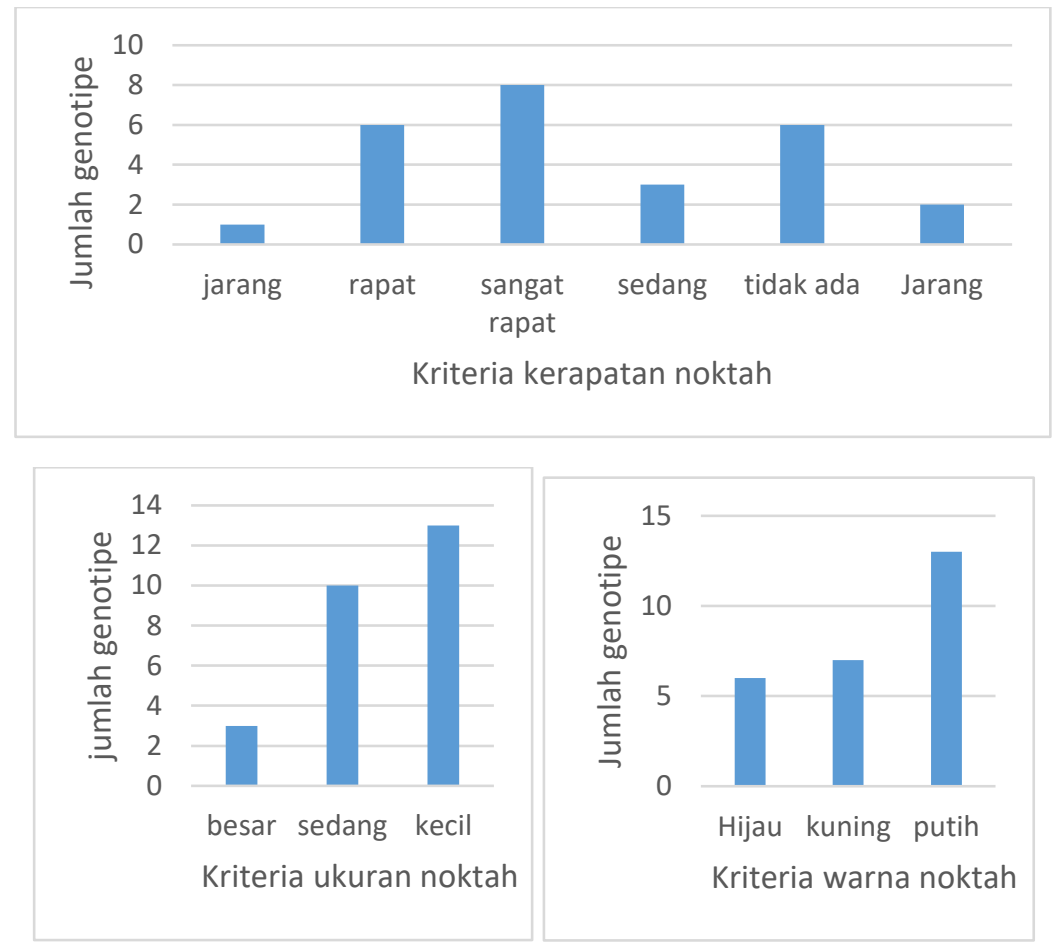

Gambar 4. Grafik jumlah genotipe melon pada kerapatan noktah (a), ukuran noktah (b), dan warna noktah (c)

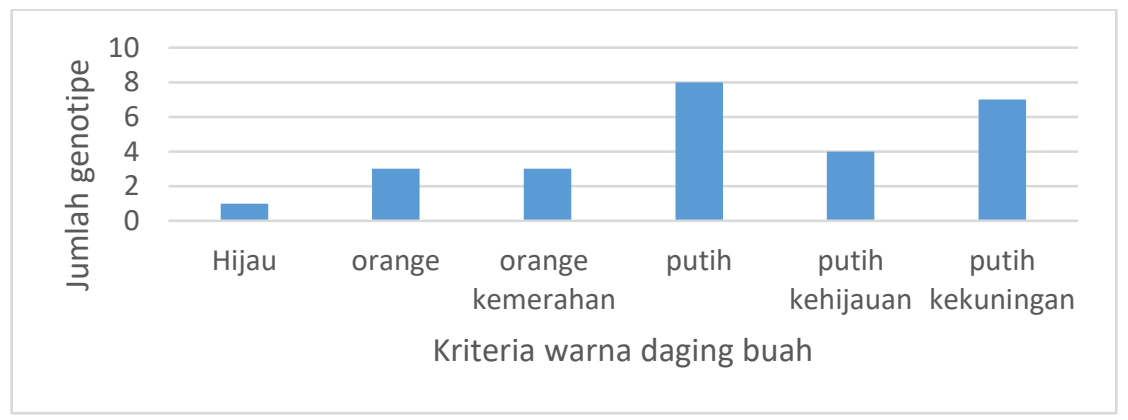

a

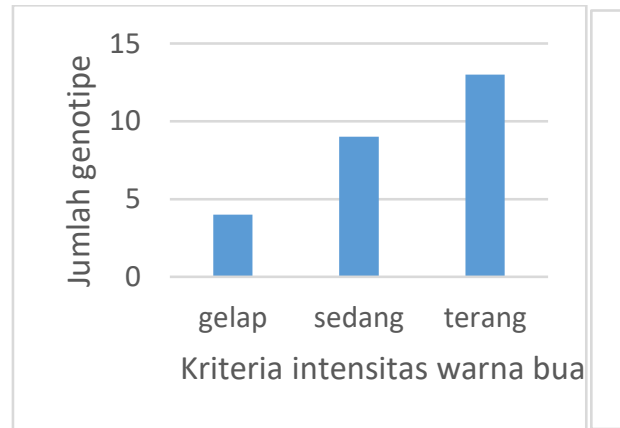

b

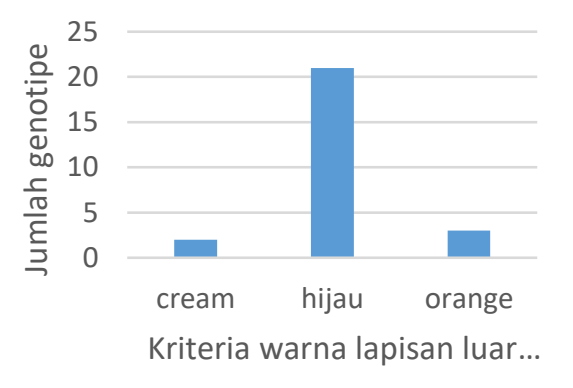

c

Gambar 5. Grafik jumlah genotipe melon pada warna daging buah (a), intensitas warna buah (b), dan warna lapisan luar daging buah (c) 


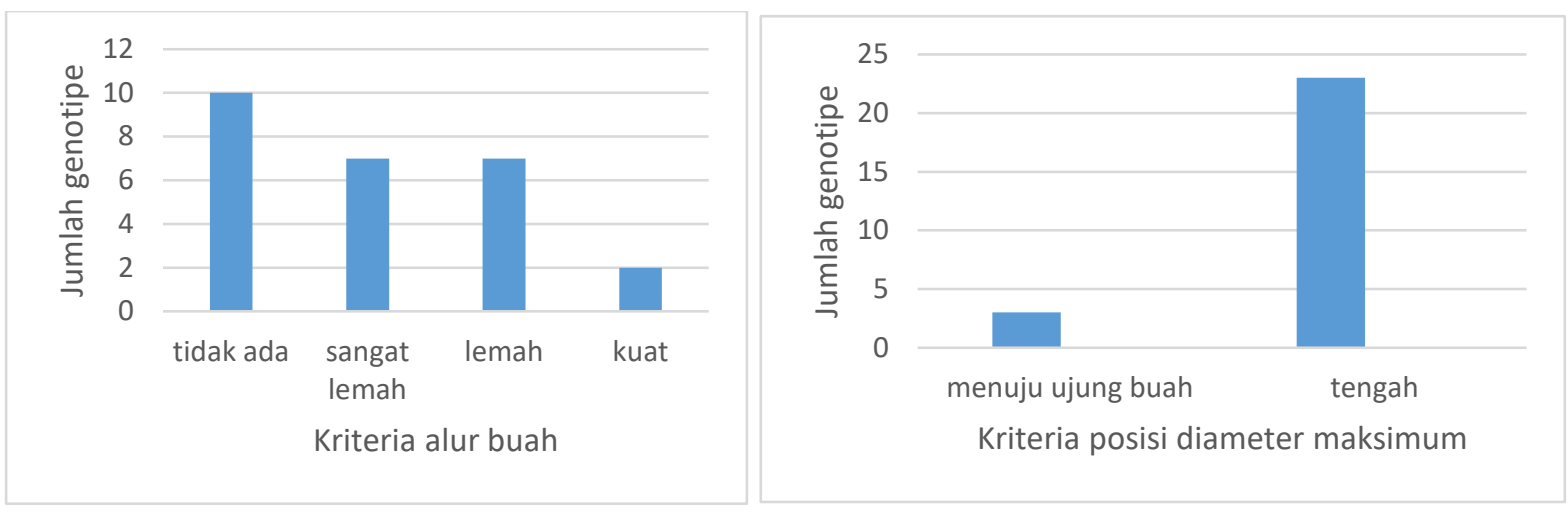

Gambar 6. Grafik jumlah genotipe melon pada alur buah (a) dan posisi diameter maksimum (b).

\section{KESIMPULAN}

Dari hasil penelitian ini, kami menyimpulkan bahwa berdasarkan analisis gerombol didapatkan karakter-karakter pada 26 genotipe melon mengelompok dan terpisah pada koefesien ketidakmiripan 22 dan 26 yang nantinya akan dijadikan tetua. Karakter buah yang diamati memiliki kriteria yang beragam pada 26 genotipe melon. Hal ini akan memudahkan seleksi untuk mendapatkan karakter buah yang diinginkan.

\section{DAFTAR PUSTAKA}

Afandi, A. F. (2018). Alasan Orang Suka Buah Melon.

Ariawan, I. A., IPutu, E. K. A., dan Putu, N. (2013). Komparasi Analisis Gerombol (Cluster) dan Biplot dalam Pengelompokan. E-Jurnal Matematika, 2(4), 17-22.

Badan Pusat Statistik. (2019). Produksi Tanaman Buah-buahan 2019. Di akses pada Desember 2020 melalui https://www.bps.go.id/indicator/55/62/1/ produksi-tanaman-buah-buahan.html

Daryono, B. S., Hayuningtyas, S. D., dan Maryanto, S. D. (2012). Perakitan Melon (Cucumis melo L.) Kultivar Melodi Gama 3 dalam Rangka Penguatan Industri Pertanian Nasional.

Ezura, H., and Owino, W.O. 2008. Melon, an alternative model plant for elucidating fruit ripening. Plant Sci. 175:121-129.
Fauzi, Y., Susilo, B., Mayasari, Z. M. (2009, December). Analisis Kesesuaian Lahan Wilayah Pesisir Kota Bengkulu Melalui Perancangan Model Spasial dan Sistem Informasi Geografis (SIG). In Forum Geografi (Vol. 23, No. 2, pp. 101-111).

Garcia-Mas, J., Benjak, A., Sanseverino, W., Bourgeois, M., Mir, G., González, V. M., Puigdomènech, P. (2012). The genome of melon (Cucumis melo L.). Proceedings of the National Academy of Sciences, 109(29), 11872-11877.

Glenn, K. C., Alsop, B., Bell, E., Goley, M., Jenkinson, J., Liu, B., Vicini, J. L. (2017). Bringing new plant varieties to market: plant breeding and selection practices advance beneficial characteristics while minimizing unintended changes. Crop Science, 57(6), 2906-2921.

Herwibowo, K., \& Budiana, N. S. (2014). Hidroponik Sayuran. Penebar Swadaya Grup.

Huda, A. N., Suwarno, W. B., Maharijaya, A. (2017). Keragaman genetik karakteristik buah antar 17 genotipe melon (Cucucmis melo L.). Jurnal Hortikultura Indonesia, 8(1), 1-12.

Kerje, T. (2003). Descriptors for Melon (Cucumis melo, L.). Internacional Plant Genetic Resources Institute, Rome, Italy.

Liu, K., Goodman, M., Muse, S., Smith, J. S., Buckler, E., Doebley, J. (2003). Genetic Structure and Diversity among Maize Inbred Lines as Inferred from DNA Microsatellites. Genetics, 165(4), 2117-2128. 
Nuraida, D. (2012). Pemuliaan tanaman cepat dan tepat melalui pendekatan marka molekuler. El-Hayah Jurnal Biologi, 2(2).

Ortiz, R., Taba, S., Chávez Tovar, V. H., Mezzalama, M., Xu, Y., Yan, J., Crouch, J. H. (2010). Conserving and enhancing maize genetic resources as global public goods-A perspective from CIMMYT. Crop Science, 50(1), 13-28.

https://doi.org/10.2135/cropsci2009. 06.0297.

Putra, H. K., Hardjoko, D., Widijanto, H. (2013). Penggunaan pasir dan serat kayu Aren sebagai media tanam terong dan tomat dengan sistem hidroponik. Agrosains: Jurnal Penelitian Agronomi, 15(2), 36-40.

Rakhi, R., and Rajamony, L. (2006).

Variability, heritability and genetic advance in landraces of culinary melon (Cucumis melo L.). Journal of Tropical Agriculture, 43, 79-82.

Robinson, R.W., and Decker-W alters, D.S. 1999. Cucurbits. CAB International, New York, US.

Roidah, I. S. (2015). Pemanfaatan lahan dengan menggunakan sistem hidroponik. Jurnal Bonorowo, 1(2), 4349.

Satya, A. T., Harjoko, D., and Ferdyana, W. C. (2017). Pertumbuhan Tomat pada Media Pasir Pantai secara Hidroponik. Jurnal Pertanian UNS, 1(1), 281-285.

Sari, N., and Solmaz, I. (2005, September). Fruit characterization of some Turkish melon genotypes. In III International
Symposium on Cucurbits 731 (pp. 103109).

Sobilhaqq, Z. O. L. I. A. N. D. (2015). Penentuan Kebutuhan Air Irigasi Dan Pemupukan Bawang Merah (Allium Cepa) Secara Hidroponik Dengan Media Pasir. Skripsi. Institut Pertanian Bogor.

Salamah, U., Suwarno, W.B., Aswidinnoor, H. (2016, November). Tingkat ketidakmiripan genotipe-genotipe jagung (Zea Mays L.) Generasi S1 dan S2 untuk pembentukan tetua. Prosiding pada seminar Seminar Nasional Inovasi Teknologi Pertanian Modern Mendukung Pembangunan Pertanian Berkelanjutan di Bengkulu 8 November 2016.

Tenda, E., Tulalo, M., Miftahorrachman. 2009. Hubungan kekerabatan genetik antar sembilan aksesi kelapa asal Provinsi Sulawesi Utara. Jurnal Littri. 15(3): 139-144.

Wahyuningsih, A., Fajriani, S., and Aini, N. (2017). Komposisi nutrisi dan media tanam terhadap pertumbuhan dan hasil tanaman pakcoy (Brassica rapa 1.) sistem hidroponik. Jurnal Produksi Tanaman, 4(8).

Weber, N., Halpin, C., Hannah, L.C., Jez, J.M., Kough, J., Parrott, W. 2012. Editor's choice: Crop genome plasticity and its relevance to food and feed safety of genetically engineered breeding stacks. Plant Physiol, 160:1842-1853. doi:10.1104/pp.112.204271. 